\title{
Comparison between bioelectrical impedance analysis and anthropometric indices in hypertensive patients
}

\author{
Porównanie analizy bioimpedancyjnej ze wskaźnikami antropometrycznymi u chorych \\ z nadciśnieniem tętniczym
}

Department of Cardiology and Internal Diseases, Military Institute of Medicine, Warsaw, Poland

Correspondence: Paweł Krzesiński, Department of Cardiology and Internal Diseases, Military Institute of Medicine, Szaserów 128, 04-141 Warsaw, Poland, tel./fax: +48 261 816372 , +48 261 817 707, e-mail: pkrzesinski@wim.mil.pl

\begin{abstract}
Aim: Obesity is one of the most crucial challenges of contemporary medicine. Bioelectrical impedance analysis is a useful tool to identify individuals with increased fat mass. However, the equipment is relatively expensive, especially compared to basic anthropometric methods. The aim of this study was to evaluate the relations between anthropometric indices and bioelectrical impedance analysis in patients with uncomplicated arterial hypertension. Material and methods: In 137 hypertensives the correlations between fat mass (absolute, FM; relative, \%FM) and anthropometric parameters (body mass index, BMI; waist circumference, WC; waist-to-hip ratio, WHR; waist-to-height ratio, WHtR; body adiposity index, BAI; visceral adiposity index, VAI) were analysed. Results: Classic anthropometrics correlated well with bioimpedance indices of adipose tissue content: \%FM vs. BAI $(R=0.77)$, WHtR $(R=-0.54)$, BMI $(R=0.52)$, WC $(R=0.29)$; FM vs. BMI $(R=0.82)$, WC $(R=0.66)$, BAI $(R=0.58)$, VAI $(R=0.26)$, WHtR $(R=0.23)$, WHR $(R=0.19)$. In females BMI, WC and BAI showed the strongest correlations with adiposity. In males they were WHtR and WC. Conclusions: Some anthropometric measurements show good agreement with bioelectrical impedance analysis and can be considered a valid surrogate for body composition assessment in the case of its inaccessibility. In hypertensive women WC and BMI seem to be the most precise in the assessment of \%FM, while in men WHtR and WC are more useful.
\end{abstract}

Keywords: obesity, hypertension, adipose tissue, bioelectrical impedance

Cel: Otyłość należy do głównych wyzwań współczesnej medycyny. Analiza bioimpedancyjna stanowi użyteczne narzędzie identyfikacji osób ze zwiększoną masą tkanki tłuszczowej. Niestety, sprzęt do analizy bioimpedancyjnej jest dość kosztowny, zwłaszcza w porównaniu z podstawowymi metodami antropometrycznymi. Celem pracy była ocena związku pomiędzy pomiarami antropometrycznymi a analizą bioimpedancyjną u pacjentów z niepowikłanym nadciśnieniem tętniczym. Materiał i metody: U 137 osób z nadciśnieniem tętniczym oceniono korelacje między ilością tkanki tłuszczowej (bezwzględnej, fat mass, FM; względnej, \%FM) a parametrami antropometrycznymi (wskaźnik masy ciała, body mass index, BMI; obwód talii, waist circumference, WC; wskaźnik talia-biodra, waist-to-hip ratio, WHR; wskaźnik talia-wzrost, waistto-height ratio, WHtR; wskaźnik otłuszczenia ciała, body adiposity index, BAI; wskaźnik wisceralnej - trzewnej tkanki tłuszczowej, visceral adiposity index, VAI). Wyniki: Klasyczne pomiary antropometryczne korelowały z bioimpedancyjnymi wskaźnikami zawartości tkanki tłuszczowej: \%FM vs BAI $(R=0,77)$, WHtR $(R=-0,54)$, BMI $(R=0,52)$, WC $(R=0,29)$; FM $v s$ BMI $(R=0,82)$, WC $(R=0,66)$, BAI $(R=0,58)$, VAI $(R=0,26)$, WHtR $(R=0,23)$, WHR $(R=0,19)$. U kobiet najsilniejszy związek z ilością tkanki tłuszczowej wykazywały BMI, WC i BAI, zaś u mężczyzn - WHtR i WC. Wnioski: Niektóre pomiary antropometryczne wykazują wysoką zgodność z analizą bioimpedancyjną i mogą być brane pod uwagę jako zastępcze wskaźniki oceny składu ciała w przypadku braku możliwości jej zastosowania. U kobiet z nadciśnieniem tętniczym najbardziej precyzyjne w ocenie \%FM okazują się WC i BMI, podczas gdy u mężczyzn są to WHtR i WC.

Słowa kluczowe: otyłość, nadciśnienie tętnicze, tkanka tłuszczowa, bioimpedancja 


\section{INTRODUCTION}

$\mathrm{O}$ besity is one of the most crucial challenges of contemporary medicine. It is well established that obesity increases the risk of developing numerous cardiometabolic complications including arterial hypertension $(\mathrm{AH})$, insulin resistance, diabetes and dyslipidaemia. The estimated percentage of overweight people worldwide is over one third ${ }^{(1-4)}$. Due to its prevalence and negative influence of obesity on health, dealing with this disorder seems to be crucial for prophylaxis and treatment of cardiovascular diseases (CVD). Classic anthropometric measurement methods have many limitations and more accurate tools to estimate adipose tissue content are still sought. As an example, body mass index (BMI) ${ }^{(5)}$ formula does not account for the proportion between body fat mass and fat free mass, which can result in misleading interpretation of results, especially in athletes. Gender and age also matter. Thus, to estimate body composition properly, it is recommended to apply a wide range of anthropometric indices, such as: BMI, waist circumference (WC) ${ }^{(5)}$, waist-to-hip ratio $(\mathrm{WHR})^{(5)}$, waist-to-height ratio $(\mathrm{WHtR})^{(5)}$, visceral adiposity index $(\mathrm{VAI})^{(6)}$ and body adiposity index $(\mathrm{BAI})^{(7)}$.

The recent rapid development of non-invasive methods in medicine has delivered numerous methods to estimate body fat mass, such as dual-energy X-ray absorptiometry (DEXA), regarded as the "gold standard" in clinical practice, magnetic resonance assessment, or bioelectrical impedance analysis (BIA). BIA as a body composition analysis method was firstly proven to be effective by Lukaski et al. ${ }^{(8)}$. This method is based on the fact that under alternating electrical excitation biological cells and tissues produce complex electrical impedance which depends on tissue composition ${ }^{(9-12)}$. Since BIA is a simple, non-invasive and safe measurement method, it may be a useful tool to identify individuals with increased fat mass. However, the equipment is relatively expensive, especially compared to basic anthropometric methods.

Fat mass assessment seems to be especially useful in patients classified as being at a low/moderate cardiovascular risk. This population, including patients with uncomplicated $\mathrm{AH}$, is large and it is difficult to provide BIA in all cases. Therefore, we hypothesize that there are some classical anthropometric indices that, depending on sex, can substitute BIA with clinically accepted consistency.

The aim of this analysis was to evaluate the relations between the anthropometric measures of obesity and body tissue composition evaluated by BIA in patients with uncomplicated AH.

\section{MATERIAL AND METHODS}

\section{Study group}

The analysis included 137 patients (94 men, mean age $44.9 \pm 10.4$ ) with AH defined as elevated blood pres- exclusion criteria were described in our previous paper ${ }^{(13)}$. The study protocol was approved by the Bioethics Committee of the Military Institute of Medicine (No. 21/WIM/2011). All of the participants provided their written consent to take part in the study. The project was registered at ClinicalTrials.gov (NCT01996085).

\section{Clinical assessment}

Office BP measurement was performed automatically (Omron M4 Plus, Japan). Systolic blood pressure (SBP) and diastolic blood pressure (DBP) were measured in a quiet room, in the presence of a trained physician or nurse, after a minimum of 5 minutes of resting in a sitting position. The measurements of anthropometric parameters such as weight, height, WC and hip circumference (HC) were performed according to the recommended methodology $y^{(14)}$. The measured values were used in calculations to obtain the following indices: BMI, WHtR, WHR, BAI and VAI. The formulas are presented in Tab. 1.

Bioelectrical impedance analysis was performed using multifrequency segmental body composition analyser TANITA MC-780 MA (TANITA Corporation, Tokyo, Japan) by experienced, trained staff according to standardized procedures (after overnight fast, light clothes, standing position). The following parameters were analysed: absolute fat mass (FM) and relative fat mass (\%FM).

\section{Laboratory tests}

Biochemical analyses were performed using peripheral venous blood. Blood samples were taken in the morning (between 7:30 and 8:30 AM) after a minimum of 6 hours of fasting. The following parameters were taken into consideration: total cholesterol (TC), high density lipoproteins (HDL), low density lipoproteins (LDL), fasting glucose (FG) and triglycerides (TG).

\section{Statistical analysis}

The statistical analysis was performed using Statistica 12.0 software (StatSoft, Inc.). The distribution and normality of the data were assessed by visual inspection and the

\begin{tabular}{|c|c|}
\hline Parameter & Formula \\
\hline $\mathrm{BMI}^{(5)}$ & Body mass / height ${ }^{2}\left(\mathrm{~kg} / \mathrm{m}^{2}\right)$ \\
\hline $\mathrm{WHtR}^{(5)}$ & $W C(\mathrm{~cm}) /$ height $(\mathrm{cm})$ \\
\hline WHR ${ }^{(5)}$ & $W C(\mathrm{~cm}) / \mathrm{HC}(\mathrm{cm})$ \\
\hline $\mathrm{BAI}^{(7)}$ & {$[\mathrm{HC}(\mathrm{cm}) /$ height $(\mathrm{m})]-18$} \\
\hline \multirow[t]{2}{*}{$\mathrm{VAl}^{(6)}$} & Male: $[\mathrm{WC} / 39.68+(1.88 \times \mathrm{BMI})] \times(\mathrm{TG} / 1.03) \times(1.31 / \mathrm{HDL})$ \\
\hline & Female: $[\mathrm{WC} / 36.58+(1.89 \times \mathrm{BMI})] \times(\mathrm{TG} / 0.81) \times(1.52 / \mathrm{HDL})$ \\
\hline \multicolumn{2}{|c|}{$\begin{array}{l}\text { BMI - body mass index; WHtR - waist-to-height ratio; WC - waist } \\
\text { circumference; WHR - waist-to-hip ratio; HC - hip circumference; } \\
\text { BAI - body adiposity index; VAI - visceral adiposity index; TG - triglycerides } \\
\text { HDL - high density lipoproteins. }\end{array}$} \\
\hline
\end{tabular}

Tab. 1. Anthropometric parameters and its formulas 


\begin{tabular}{|c|c|c|}
\hline & & Mean $\pm S D$ \\
\hline \multirow{9}{*}{$\begin{array}{l}\text { Anthropometric } \\
\text { indicies }\end{array}$} & \%FM (\%) & $26.8 \pm 3.3$ \\
\hline & FM (kg) & $23.9 \pm 8.5$ \\
\hline & Body mass (kg) & $87.8 \pm 16.0$ \\
\hline & BMI $\left(\mathbf{k g} / \mathbf{m}^{2}\right)$ & $29.0 \pm 4.2$ \\
\hline & WC (m) & $0.99 \pm 0.12$ \\
\hline & BAI (u) & $29.5 \pm 5.2$ \\
\hline & $\operatorname{VAI}(u)$ & $4.72 \pm 3.25$ \\
\hline & WHR & $0.93 \pm 0.08$ \\
\hline & WHtR & $0.57 \pm 0.07$ \\
\hline \multirow{7}{*}{$\begin{array}{l}\text { Additional clinical } \\
\text { characteristics }\end{array}$} & $\mathrm{TC}(\mathrm{mg} / \mathrm{dL})$ & $223.9 \pm 39.6$ \\
\hline & HDL (mg/dL) & $57.7 \pm 18.6$ \\
\hline & LDL (mg/dL) & $145.1 \pm 34.1$ \\
\hline & TG (mg/dL) & $158.2 \pm 78.4$ \\
\hline & $\mathrm{FG}(\mathrm{mg} / \mathrm{dL})$ & $98.6 \pm 11.3$ \\
\hline & $\mathrm{SBP}(\mathrm{mm} \mathrm{Hg})$ & $141.2 \pm 13.0$ \\
\hline & DBP (mm Hg) & $90.4 \pm 9.0$ \\
\hline \multicolumn{3}{|c|}{$\begin{array}{l}\text { SD - standard deviation; \%FM - relative fat mass; FM - absolute fat mass; } \\
\text { BMI - body mass index; WC - waist circumference; BAI - body adiposity } \\
\text { index; VAI - visceral adiposity index; WHR - weight-to-hip ratio; } \\
\text { WHtR - weight-to-height ratio; TC - total cholesterol; HDL - high density } \\
\text { lipoproteins; LDL - low density lipoproteins; TG - triglycerides; FG - fasting } \\
\text { glucose; SBP - systolic blood pressure; DBP - diastolic blood pressure. }\end{array}$} \\
\hline
\end{tabular}

Tab. 2. General characteristics of the studied population

Kolmogorov-Smirnov test. Continuous variables were presented as means \pm standard deviations $(S D)$. The relations between the analysed parameters were investigated with Pearson's (Spearman's) correlation coefficients. A $p$ value of $<0.05$ was taken to indicate statistical significance.

\section{RESULTS}

\section{Basic characteristics of the study group}

Men constituted most of the group (68.6\%). Almost half of the subjects were obese $(43 \%)$. Basic clinical data are

Women

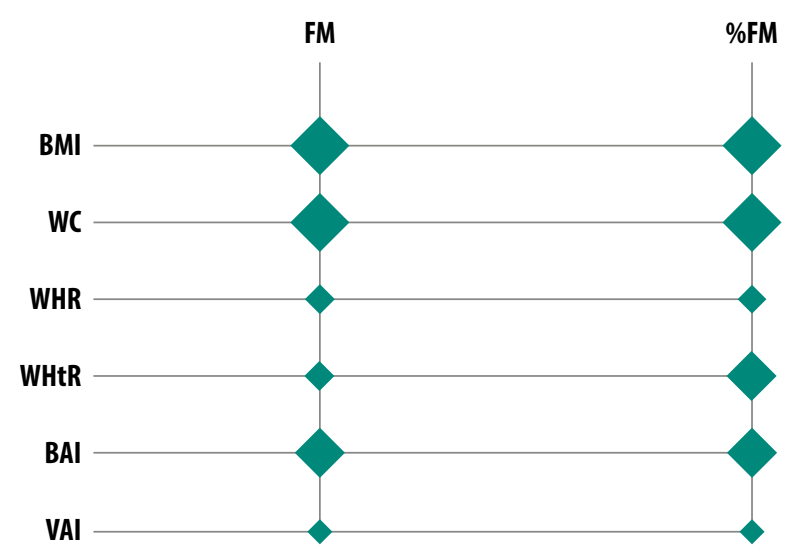

\begin{tabular}{|c|c|c|c|c|}
\hline & \multicolumn{2}{|c|}{ FM } & \multicolumn{2}{c|}{ \%FM } \\
\cline { 2 - 5 } & $\boldsymbol{R}$ & $\boldsymbol{p}$ & $\boldsymbol{R}$ & $\boldsymbol{p}$ \\
\hline BMI & 0.82 & $<0.001$ & 0.52 & $<0.001$ \\
\hline WC & 0.66 & $<0.001$ & 0.29 & $<0.001$ \\
\hline WHR & 0.19 & 0.031 & 0.10 & 0.243 \\
\hline WHtR & 0.23 & 0.007 & 0.55 & $<0.001$ \\
\hline BAI & 0.57 & $<0.001$ & 0.77 & $<0.001$ \\
\hline VAI & 0.26 & 0.002 & 0.05 & 0.569 \\
\hline
\end{tabular}

FM - absolute fat mass; \%FM - relative fat mass; BMI - body mass index; WC - waist circumference; WHR - weight-to-hip ratio; WHtR - weight-toheight ratio; BAI - body adiposity index; VAI - visceral adiposity index.

Tab. 3. Correlations between anthropometric parameters and BIA fat mass indices in the whole group

shown in Tab. 2. More detailed characteristics of the studied group were described previously ${ }^{(13)}$.

\section{Correlation in the whole study group}

In the whole group the power of correlations between anthropometric parameters and FM in descending order was as follows: BMI, WC, BAI, WHtR, WHR, VAI. Nonetheless, the power of correlations between anthropometric parameters and \%FM was different: BAI, WHtR, BMI, WC, WHR, VAI (Tab. 3).

\section{Correlation in gender subgroups}

The relations between anthropometrics and BIA indices were found to be dependent on gender (Fig. 1). In women all of the considered correlations were statistically significant (Tab. 4). The power of correlations between anthropometric parameters and FM in descending order was as follows: BMI, WC, BAI, WHtR, WHR, VAI, and for \%FM: BMI, WC, WHtR, BAI, WHR, VAI (Tab. 4).

In men all of the considered correlations were statistically significant apart from FM vs. WHtR (Tab. 5). The power

\section{Men}

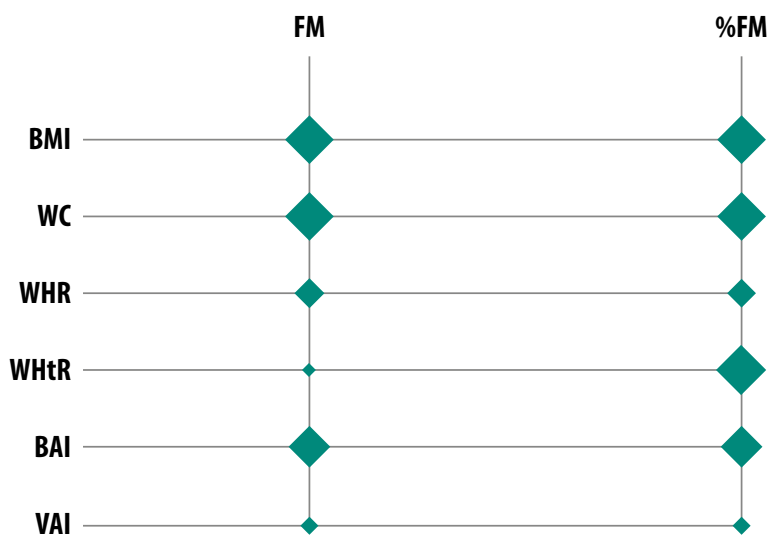

Fig. 1. Power of correlations between fat mass indices and anthropometric indices in women (left side) and men (right side). The size of diamonds corresponds with the values of correlation coefficients $\left(\mathrm{R}^{2}\right)$ 


\begin{tabular}{|c|c|c|c|c|}
\hline \multirow{2}{*}{ BMI } & \multicolumn{2}{|c|}{ FM } & \multicolumn{2}{c|}{ \%FM } \\
\cline { 2 - 5 } & $\boldsymbol{R}$ & $\boldsymbol{p}$ & $\boldsymbol{R}$ & $\boldsymbol{p}$ \\
\hline WC & 0.95 & $<0.001$ & 0.90 & $<0.001$ \\
\hline WHR & 0.44 & $<0.001$ & 0.84 & $<0.001$ \\
\hline WHtR & 0.51 & $<0.003$ & 0.44 & 0.003 \\
\hline BAI & 0.78 & $<0.001$ & 0.78 & $<0.001$ \\
\hline VAI & 0.38 & 0.010 & 0.73 & $<0.001$ \\
\hline
\end{tabular}

FM - absolute fat mass; \%FM - relative fat mass; $\mathbf{B M I}$ - body mass index; WC - waist circumference; WHR - weight-to-hip ratio; WHtR - weight-toheight ratio; BAI - body adiposity index; VAI - visceral adiposity index.

Tab. 4. Correlations between anthropometric parameters and $B I A$ results in the female subgroup

\begin{tabular}{|c|c|c|c|c|}
\hline \multirow{2}{*}{} & \multicolumn{2}{|c|}{ FM } & \multicolumn{2}{c|}{ \%FM } \\
\cline { 2 - 5 } & $\boldsymbol{R}$ & $\boldsymbol{p}$ & $\boldsymbol{R}$ & $\boldsymbol{p}$ \\
\hline BMI & 0.82 & $<0.001$ & 0.68 & $<0.001$ \\
\hline WC & 0.85 & $<0.001$ & 0.76 & $<0.001$ \\
\hline WHR & 0.45 & $<0.001$ & 0.48 & $<0.001$ \\
\hline WHtR & 0.18 & 0.088 & 0.77 & $<0.001$ \\
\hline BAI & 0.52 & $<0.001$ & 0.62 & $<0.001$ \\
\hline VAI & 0.32 & 0.002 & 0.27 & 0.012 \\
\hline
\end{tabular}

FM - absolute fat mass; \%FM - relative fat mass; $\mathbf{B M I}$ - body mass index; WC - waist circumference; WHR - weight-to-hip ratio; WHtR - weight-toheight ratio; BAI - body adiposity index; VAI - visceral adiposity index.

Tab. 5. Correlations between anthropometric parameters and $B I A$ results in the male subgroup

of correlations between anthropometric parameters and FM in descending order was as follows: WC, BMI, BAI, WHR, VAI, WHtR, and for \%FM: WHtR, WC, BMI, BAI, WHR, VAI (Tab. 5).

\section{DISCUSSION}

The analysis revealed that correlations between the chosen anthropometric parameters and bioimpedance indices of fat mass are highly diverse. That dissimilarity has shown that gender should be considered in body composition assessment. Secondly, it has demonstrated that FM and \%FM should be interpreted separately.

The correlations were stronger in women than in men and anthropometric parameters were more precise in fat mass evaluation. Widely used BMI and WC were identified to be the most representative for fat mass in this subgroup. Slightly different observations concerned men. A high diagnostic value for \%FM was observed for WHtR. However, this parameter lost its value in the case of FM. The specific body fat distribution to the visceral region in men is most likely the reason for WHtR vs. \%FM and $\mathrm{WC}$ vs. \%FM correlations being the strongest in this subgroup $^{(14)}$. The differences in the correlations confirmed the well-established gender-dependent fat distribution, connected mainly with the endocrinal system and sensitivi-
Freedman et al. ${ }^{(17)}$ also observed a higher degree of collinearity between percent body fat and BMI, BAI and HC in women than in men (respectively: 0.85 vs. $0.76,0.82$ vs. 0.77 and 0.83 vs. 0.75 ) but comparable body fat and WC (0.81 vs. 0.80$)$. On the contrary, Jabłonowska-Lietz et al. ${ }^{(18)}$ did not observe such convincing correlations. They noted only slight correlations between \%FM and BMI: $R=0.26$ ( $p<0.01$ ); \%FM and BAI: $R=0.37$ (men), $R=0.39$ (women, both $p<0.001$ ). WHR correlated with \%FM only in men $(R=0.35, p<0.05)$. No significant relation was noted for $\% \mathrm{FM}$ and WHtR, VAI, WC, WHR (in women) ${ }^{(18)}$. It is puzzling, as the population in that study was comparable to ours (BMI range of $30-35 \mathrm{~kg} / \mathrm{m}^{2}$, non-diabetics, no history of hyperglycaemia and hyperlipidaemia treatment). Gender heterodoxies were also observed in adolescents ${ }^{(19)}$. The clinical implications of our results should be considered in a broader context. Although BMI is a recommended indicator of obesity, a recent study has shown it is a poorer predictor of cardiovascular events than $\% \mathrm{FM}^{(20)}$. Many factors lead to significant mistakes in the interpretation of BMI, including gender, race, high muscle mass, changes in hydration status (in particular retention of extracellular fluids) ${ }^{(21)}$. Yusuf et al. ${ }^{(22)}$ showed that the small increase in the risk of heart attack that is associated with BMI increase disappears after adjustment for abdominal adiposity. There are many subjects "metabolically obese but with normal weight," having a normal BMI and higher visceral adiposity, insulin resistance, and an increased cardiometabolic risk ${ }^{(23)}$.

Several studies have shown that WC is strongly related to visceral fat and abdominal adiposity, more than BMI and $\mathrm{WHR}^{(21)}$. Abdominal obesity increases cardiovascular risk by its association with higher metabolic activity, increased activity of sympathetic nervous system and renin-angiotensin-aldosterone system, as well as altered endothelial function ${ }^{(24-26)}$. WHtR has also been considered a strong screening tool for cardiometabolic risk in adults ${ }^{(21)}$, with some authors suggesting WHtR to be the most practical and convenient index of regional adipose tissue distribution ${ }^{(27)}$. A meta-analysis presented by Ashwell and Gibson ${ }^{(27)}$ showed that WHtR was even a better index of prognosis of diabetes, dyslipidaemia, hypertension, and risk of CVD in both sexes than WC. Corrêa et al. ${ }^{(28)}$ suggest that in elderly patients WHtR shows high precision in discrimination of visceral obesity and is more effective than WC and WHR in cardiovascular risk assessment and follow-up in clinical practice. VAI was found to be the poorest correlate in our study. However, its additive clinical value should not be ignored. Amato and Giordano ${ }^{(29)}$ point out that VAI, one of the most common indexes used in adiposity assessment, mirrors not exactly the adipose tissue amount, but its endocrine function, associated with a higher cardiometabolic risk. Jabłonowska-Lietz et al. ${ }^{(18)}$ reported that VAI significantly correlated with serum glucose, insulin concentrations and HOMA-IR. However, Bozorgmanesh et al. ${ }^{(30)}$ observed that WHtR outperformed VAI in its ability to predict the metabolic syndrome. 


\section{LIMITATIONS}

The limited number of subjects and the unbalance between sexes should be noted. The results were obtained in a particular group of patients (hypertensives) and cannot be extrapolated on the general population. The hormonal status of women, which was not accounted for in this study, should also be kept in mind.

\section{CONCLUSIONS}

Some anthropometric measurements show good agreement with BIA and can be considered a valid surrogate for body composition assessment in the case of its inaccessibility. In hypertensive women WC and BMI seem to be the most precise in the assessment of \%FM, while in men WHtR and WC are more useful. The prognostic significance of these relations should be further investigated.

\section{Conflict of interest}

The authors do not declare any financial or personal links to other persons or organizations that could adversely affect the content of this publication and/or claim rights thereto.

\section{Funding/Support and role of the sponsor}

The study was supported by the Ministry of Science and Higher Education/Military Institute of Medicine, Warsaw, Poland (grant No. 148/WIM).

\section{Acknowledgments}

We would like to thank the medical staff of the Department of Cardiology and Internal Diseases of the Military Institute of Medicine for the assistance in patient care and data collection.

\section{References}

1. Hruby A, Hu FB: The epidemiology of obesity: a big picture. Pharmacoeconomics 2015; 33: 673-689.

2. $\mathrm{Ng}$ M, Fleming T, Robinson $\mathrm{M}$ et al.: Global, regional, and national prevalence of overweight and obesity in children and adults during 1980-2013: a systematic analysis for the Global Burden of Disease Study 2013. Lancet 2014; 384: 766-781.

3. Stevens GA, Singh GM, Lu Y et al.; Global Burden of Metabolic Risk Factors of Chronic Diseases Collaborating Group (Body Mass Index): National, regional, and global trends in adult overweight and obesity prevalences. Popul Health Metr 2012; 10: 22.

4. Kelly T, Yang W, Chen CS et al.: Global burden of obesity in 2005 and projections to 2030. Int J Obes (Lond) 2008; 32: 1431-1437.

5. Wiltink J, Michal M, Wild PS et al.: Associations between depression and different measures of obesity (BMI, WC, WHtR, WHR). BMC Psychiatry 2013; 13: 223.

6. Amato MC, Giordano C, Galia M et al.; AlkaMeSy Study Group: Visceral Adiposity Index: a reliable indicator of visceral fat function associated with cardiometabolic risk. Diabetes Care 2010; 33: 920-922.

7. Bergman RN, Stefanovski D, Buchanan TA et al.: A better index of body adiposity. Obesity (Silver Spring) 2011; 19: 1083-1089.

8. Lukaski HC, Johnson PE, Bolonchuk WW et al.: Assessment of fat-free mass using bioelectrical impedance measurements of the human body. Am J Clin Nutr 1985; 41: 810-817.
9. Bera TK: Bioelectrical impedance methods for noninvasive health monitoring: a review. J Med Eng 2014; 2014: 381251.

10. Ackmann JJ: Complex bioelectric impedance measurement system for the frequency range from $5 \mathrm{~Hz}$ to $1 \mathrm{MHz}$. Ann Biomed Eng 1993; 21: 135-146.

11. Ackmann JJ, Seitz MA: Methods of complex impedance measurements in biologic tissue. Crit Rev Biomed Eng 1984; 11: 281-311.

12. Cha K, Chertow GM, Gonzalez J et al.: Multifrequency bioelectrical impedance estimates the distribution of body water. J Appl Physiol (1985) 1995; 79: 1316-1319.

13. Krzesiński P, Hałas K, Gielerak G et al.: [Cardiovascular risk and inflammatory markers in patients with hypertension]. Pol Merkur Lekarski 2015; 38: 70-76.

14. Lohman TG, Roche AF, Martorell R: Anthropometric Standardization Reference Manual. Human Kinetics Books, Champaign, IL 1988: 3-8.

15. Blaak E: Gender differences in fat metabolism. Curr Opin Clin Nutr Metab Care 2001; 4: 499-502.

16. Monda V, Salerno M, Fiorenzo M et al.: Role of sex hormones in the control of vegetative and metabolic functions of middleaged women. Front Physiol 2017; 8: 773.

17. Freedman DS, Thornton JC, Pi-Sunyer FX et al.: The body adiposity index (hip circumference $\div$ height ${ }^{1.5}$ ) is not a more accurate measure of adiposity than is BMI, waist circumference, or hip circumference. Obesity (Silver Spring) 2012; 20: 2438-2444.

18. Jabłonowska-Lietz B, Wrzosek M, Włodarczyk M et al.: New indexes of body fat distribution, visceral adiposity index, body adiposity index, waist-to-height ratio, and metabolic disturbances in the obese. Kardiol Pol 2017; 75: 1185-1191.

19. Tovar-Galvez MI, González-Jiménez E, Martí-García C et al.: Body composition in a population of school adolescents: a comparison of simple anthropometric methods and bioelectrical impedance. Endocrinol Diabetes Nutr 2017; 64: 424-431.

20. Zeng Q, Dong SY, Sun XN et al.: Percent body fat is a better predictor of cardiovascular risk factors than body mass index. Braz J Med Biol Res 2012; 45: 591-600.

21. Amato MC, Guarnotta V, Giordano C: Body composition assessment for the definition of cardiometabolic risk. J Endocrinol Invest 2013; 36: 537-543.

22. Yusuf S, Hawken S, Ounpuu S et al.; INTERHEART Study Investigators: Obesity and the risk of myocardial infarction in 27,000 participants from 52 countries: a case-control study. Lancet 2005; 366: $1640-1649$.

23. Ruderman N, Chisholm D, Pi-Sunyer X et al.: The metabolically obese, normal-weight individual revisited. Diabetes 1998; 47: 699-713.

24. de Simone G, Devereux RB, Kizer JR et al.: Body composition and fat distribution influence systemic hemodynamics in the absence of obesity: the HyperGEN Study. Am J Clin Nutr 2005; 81: 757-761.

25. Bagi Z: Mechanisms of coronary microvascular adaptation to obesity. Am J Physiol Regul Integr Comp Physiol 2009; 297: R556-R567.

26. Zoccali C, Postorino M, Marino C et al.; CREDIT Working Group: Waist circumference modifies the relationship between the adipose tissue cytokines leptin and adiponectin and all-cause and cardiovascular mortality in haemodialysis patients. J Intern Med 2011; 269: 172-181.

27. Ashwell M, Gibson S: Waist to height ratio is a simple and effective obesity screening tool for cardiovascular risk factors: analysis of data from the British National Diet and Nutrition Survey of adults aged 19-64 years. Obes Facts 2009; 2: 97-103.

28. Corrêa MM, Thumé E, De Oliveira ER et al.: Performance of the waist-to-height ratio in identifying obesity and predicting noncommunicable diseases in the elderly population: a systematic literature review. Arch Gerontol Geriatr 2016; 65: 174-182.

29. Amato MC, Giordano C: Visceral adiposity index: an indicator of adipose tissue dysfunction. Int J Endocrinol 2014; 2014: 730827.

30. Bozorgmanesh M, Hadaegh F, Azizi F: Predictive performance of the visceral adiposity index for a visceral adiposity-related risk: type 2 diabetes. Lipids Health Dis 2011; 10: 88. 